\title{
SHEDDING LIGHT ON TRANSFORMATIONAL ONLINE LEARNING USING FIVE PRACTICE BASED TENETS: ILLUMINATING THE SIGNIFICANCE OF THE SELF
}

\author{
Dr Sally Goldspink ${ }^{\mathrm{a}}$, Dr Hilary Engward ${ }^{\mathrm{b}}$ \\ aAnglia Ruskin University, Cambridge, England \\ bAnglia Ruskin University, Chelmsford, England \\ Corresponding Email: sally.goldspink@anglia.ac.uk
}

\begin{abstract}
This practitioner-led research explores the lived subjective experience of undergraduate distance learning (DL). This research is distinct to understanding DL because consideration is given to person-centred understandings as opposed to a technologically driven focus. The emphasis of individual impact is timely and necessary as the academic and professional literature questions the ability of distance learning to develop deep and transformational learning. Using data from qualitative Interpretive Phenomenological Analysis, 5 practice-based tenets are proposed to develop transformational learning: attention, acceptance, accompaniment, adaptation and action. Together, the tenets show the process of transformation beginning as the participants turn their gaze inwards then embracing new ways of thinking and acting, with the accompaniment of others - especially tutors - providing stability whilst encouraging intellectual risk-taking. This focus on self-discovery presents opportunities to promote and integrate a curiosity-based curricular, content design and assessment that shifts the acceptance of knowledge as authored by others, to learners self-authoring their own understanding; thereby creating a future-facing approach for learning autonomy and more confident dissemination of ideas. The paper concludes by suggesting that new practice-world conversations about the integration of humanistic educational ideals can go hand-in-hand with advancements in technology.
\end{abstract}

Keywords: Distance Learning, Interpretive Phenomenological Analysis, Transformation.

\section{Introduction and Purpose}

With increasing popularity of online distance learning (DL) as a means to develop learning and professional practices, this study illustrates why a refocus from the centrality of technology to the experience of learning is needed to develop deep and transformational impact. Transformative Learning Theory (TLT) is influential in understanding how adults learn (Mezirow \& Taylor, 2011; Cranton \& Kasl, 2012), but the theory is often poorly translated in educational research (Taylor \& Snyder, 2012; King 2017). Therefore, placing emphasis on how learning is experienced is timely and necessary as the academic and professional literature questions the ability of distance learning to offer transformational opportunities (Ossiannilsson \& Landgren, 2012; Todhunter, 2013). In addition, the interest placed on short term evaluations of learning is at odds with conceptualisations of TLT, where value is placed on personal significance and growth in the longer-term for the self and others. Saunders, Bamber and Trowler (2011), Borkowsky (2013), and Taylor and Cranton (2013) all maintain that evaluation of learning should be based on wider interpretations of the student experience. Arguably then, re-conceptualising the evaluation of the personal impact of distance learning is not only 
necessary, but long overdue. From a transformational perspective, learner-centred higher education is not merely a different style of teaching; the academic is required to understand authentically the need for a learner-centred approach. Therefore, the purpose of this research was to explore what DL is like for the learners themselves. In this way, online practice necessitates a new stance to identify and conceptualise the individual DL experience rather than pursuing the trend in the technological aspects of this mode of delivery.

\section{Methodology}

Using semi structured telephone interviews, the alumni from a specific undergraduate course voiced their distance learning stories. Interpretive Phenomenological Analysis (IPA). Smith, et al., (2009)was used to capture, interpret and gain a temporal insight into the participants' unique and shared narrative. Initial descriptive analysis progressed toward abstract and conceptual interpretations, whilst remaining grounded in the participants' words, thus revealing 'the extraordinary in the ordinary, the strange in the commonplace; the hidden in the obvious' (McNamara, 2005, p. 697).

\section{Interpretations; Self-Connected Learning}

In-depth analysis revealed that the experiences of DL accumulated in the participants' descriptions of change, linking affective reasoning (perceptions), thinking habits, and actions; outlining how embodied learning integrates feelings and thoughts with physical activity. As a consequence, the narratives offered can be labelled as self-connected because the physical application of thought contributed to the affective processes, as required for transformative learning. Self-connected learning thus differs from notions of self-directed learning and studentcentred learning. For example, Knowles describes self-directed learning as 'a process in which individuals take the initiative without the help of others in diagnosing their learning needs, formulating goals, identifying human and material resources, and evaluating learning outcomes' (1975, p. 18). To Nanney, student-centred learning is, 'a broad teaching approach that encompasses replacing lectures with active learning, integrating self-paced learning programs and/or cooperative group situations, ultimately holding the student responsible for his own advances in education' $(2004$, p. 1). In contrast, this research identifies the concept of selfconnected learning as the embodied experience of learning for the self, nurtured in a caring environment to empower ongoing self-efficacy, curiosity and choice. The difference this insight offers is the notion of embodiment, which we have termed as self-connected learning. Selfconnected learning, as demonstrated in the data, illuminates introspective development as more powerful than externally based content recall, where participants' refer to multiple meanings when making connections, including;

- technological connections to access virtual learning

- connections in the pedagogic design between learning activity and assessment

- connections from content to external links

- professional connection to the content via previous and current experience

- connections with peers (in and outside of the course)

- connections with tutors

However, these 'connections' necessitate action, whether switching on a computer, checking emails, constructing a discussion board message, or talking to colleagues in practice. Action involves decisions based on notions about the self in relation to the context of the learning experience. Thus, connections between the learning and the self influence how other connections are interpreted and used. As a result, 'self-connected' learning becomes apparent when meaningful participation is based on the dynamic use of self, suggesting learning is part of the person (Dewey, 1938; Rogers \& Freiberg, 1994). Without connecting primarily with the self, other connections (i.e. technological, tutorial and informational) are susceptible to being devoid 
of personal meaning. This means that for online educationalists, refocusing toward the whole person initiates authentic and embodied learning experiences. Consequently, self-connection to learning adds to the pedagogy of contemporary higher education (Pring, 2015), as a propositional reminder, of the centrality of the embodied experience of learning online that is needed to nurture transformative learning.

The outcome of this research is therefore challenging for learners and faculty as it questions us to reconsider how DL is understood, managed and delivered. In this research, the part-time, distance learning alumni recounted the complexity of their own learning, and their application of that learning to their future professional practices. The participants revealed that they did not learn 'virtually', they learned within the reality of themselves, via their life context - a life continuing behind the technological screen (Adams, 2014). This study provides evidence of the DL experience in terms of embodied, self-connected engagement and from this, five tenets are proposed to aid online educationalists to develop self-connected learning.

\section{Using Five Practice Based Tenets}

To shed light on the core features of self-connected learning, diagram 1 reveals 5 practice-based tenets as important in the participants' transformational experience: attention, acceptance, accompaniment, adaptation and action. Together, the tenets reflect the process of transformation beginning as the participants turn their gaze inwards and embracing new ways of thinking and acting, and with the accompaniment of others - especially tutors - providing stability whilst encouraging intellectual risk-taking. Sharing the learning experience with a trusted companion (e.g. the tutor), togetherness is recognised in separation. Focusing on selfdiscovery presents opportunities to promote and integrate a curiosity-based curricular, content design and assessment that shifts the acceptance of knowledge as authored by others, to learners self-authoring their own understanding; thereby creating a future-facing approach for learning autonomy and more confident dissemination of ideas.

Diagram 1: Pedagogical tenets flowing into self-connected learning

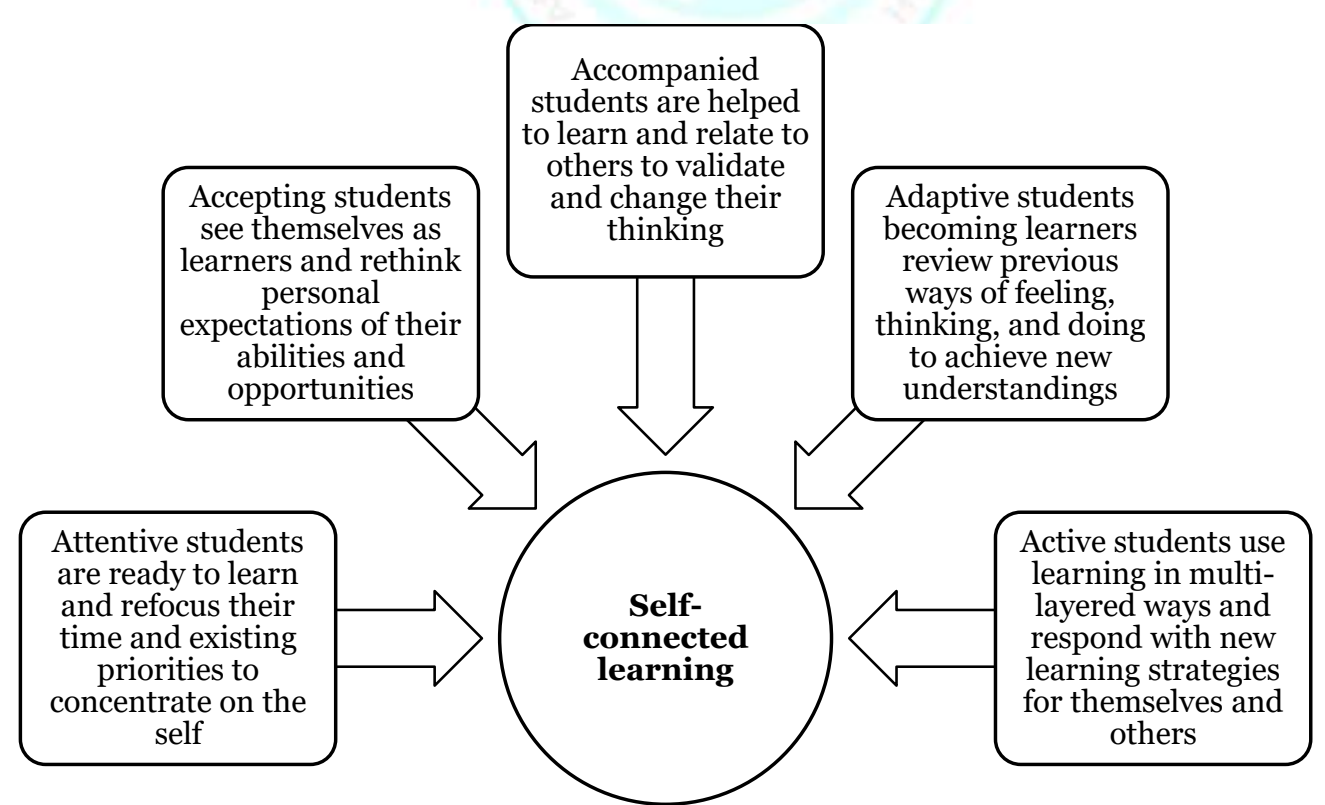

The participants' learning experiences connect internalised appraisals of their past and present to future concerns and aspirations. In doing so, self-connected learning produces detectable and continuous cognitive, affective, and behavioural, inter- and intra-personal consequences. 
Significantly, the 'human' quality of the learning environment created by tutors, including technological factors of ease of use and relevance, are important features in understanding why the participants connected with themselves, through their DL experience. Hence, the conceptual context of self-connected learning fits neatly with Transformational Learning Theory as 'a structural change in the way we see ourselves and our relationships' (Mezirow, 1978, p. 100).

\section{Insights for Practice}

When the self is connected with learning, independent and critical reflection is more likely to occur and be shared with others. Therefore, attending to the learner rather than to the technology provides DL opportunities for transformative education. By reframing focus, the centrality of the relationship between the tutor and the learner is shown in their respective active and complementary roles: tutors design opportunities for learners to make their own discoveries by linking and evaluating new and existing knowledge in the context of their own experiences (Dewey, 1933; Knowles, 1975). Taking a humanistic approach, the 'inner world' of the learner is respected as tutors offer different levels of support during the learning experience. The tutor starts as a navigational aid, then a critical friend and finally a sound box for selfdirected ideas. In practice, the participants revealed a process of structured learning, followed by supported activities which led them on to self-directed participation. Through the transitional stages of the tutorial relationship, the promotion of individual self-esteem and confidence are crucial because how a person feels about their learning influences what they think or do. So, rather than creating dependency on the technological presentation of content, the academic care shown in individualised communications encourages the learner to embody that learning, and learning is made more meaningful for them in their practice worlds. Table 3 indicates how self-connected learning can be illuminated through pedagogic practice.

Table 3: Summary of recommendations and application to educational practice

\begin{tabular}{|l|l|}
\hline Recommendation & Application \\
\hline $\begin{array}{l}\text { Nurturing self- } \\
\text { a transformational } \\
\text { tutorial approach }\end{array}$ & $\begin{array}{l}\text { Self-connected learning assumes learners have their own unique } \\
\text { ways of learning, requiring overt and meaningful pedagogic } \\
\text { approaches and practices. Explaining the curriculum, content } \\
\text { structure, and assessment procedure and tutor actions provides a } \\
\text { transparent base from which learners can take ownership of their } \\
\text { curiosity and self-connect to their own learning. In doing so, } \\
\text { personalised attention, care, and feedback transcends the online } \\
\text { classroom, with the explicit aim of filtering self-connected learning } \\
\text { into everyday life. }\end{array}$ \\
\hline $\begin{array}{l}\text { Simulating curiosity in a } \\
\text { nurturing online } \\
\text { environment }\end{array}$ & $\begin{array}{l}\text { The newness of the distance learning experience is empathetically } \\
\text { accepted by tutors and learners are encouraged to work proactively } \\
\text { with the novelty of their learning situation. Learners are empowered } \\
\text { to be curious through safe, psychological engagement with } \\
\text { uncertainty in order to preserve and build self-esteem, with tutors } \\
\text { providing stability at a time of change. }\end{array}$ \\
\hline $\begin{array}{l}\text { Promoting ownership of } \\
\text { the learning process }\end{array}$ & $\begin{array}{l}\text { When curriculum design, structure, content and assessment } \\
\text { combine, learners can be encouraged to refocus their attention } \\
\text { toward the self. Redirecting learning outcomes toward the } \\
\text { experience of learning and the application of new learning replaces } \\
\text { faculty as 'knowledge providers' to guiding companions who } \\
\text { advocate questioning; accompanying the learner to confidently } \\
\text { participate in their own, dynamic learning experience. }\end{array}$ \\
\hline
\end{tabular}




\section{Conclusions}

When the self is connected (embodied) with the learning, independent and critical reflection is more likely to occur and be shared with others. Therefore, developing the confidence to be curious is necessary given that beyond the academy, learners must be cognitively, affectively and practically equipped and ready to progress by themselves, when tutors and courses are no longer accessible (Palmer \& Zajonc, 2010; QAA, 2014). Higher education plays a commanding role in preparing learners for an unknown future, so the aims of undergraduate courses encompass the capability to search and critically select knowledge and problem solve, resulting in self-directed, knowledge producers. 


\section{References}

i. Adams, C., 2014. What's in a Name? The Experience of the Other in Online Classrooms. Phenomenology \& Practice, 1(1), pp. 51-67.

ii. Aspin, D., Chapman, J., Evans, K. \& Bagnell, R., 2012. Second International Handbook of Lifelong Learning. 2nd ed. London: Springer.

iii. Borkowsky, A., 2013. Monitoring Adult Learning Policies: A Theoretical Framework and indicators, s.l.: EDU Working Paper 88. OECD.

iv. Cranton, P. \& Kasl, E., 2012. A Response to Michael Newman's 'Calling Transformative Learning into Question: Some Mutinous Thoughts. Adult Education Quarterly, 62(4), pp. 393-398.

v. Dewey, J., 1938. Experience and Education. The Kappa Di Lecturer Series,. In: J. Dewey, ed. First Touchstone Edition. New York: Touchstone.

vi. $\quad$ King, K., 2017. Technology and Innovation in Adult Learning. San Fransisco, CA: Jossey-Bass..

vii. $\quad$ Knowles, M., 1975. Self-Directed Learning: A Guide for Learners and Teachers. New York: Association Press.

viii. $\quad$ Magolda, M. B., 2014. Self-Authorship: The Key to Student Learning Aspirations. s.l., Aspirations Symposium, Virginal Tech, USA. 2-3 November 2014.

ix. $\quad$ Mezirow, J., 1978. Perspective Transformation. Adult Education Quarterly, 28(2), pp. 100-110.

x. Mezirow, J. \& Taylor, E., 2011. Transformative Learning in Practice, Insights from Community, Workplace, and Higher Education. San Francisco, CA: John Wiley and Sons.

xi. $\quad$ Nanney, B., 2004. Student-Centred Learning. Proceedings from the 3rd European Conference in E-Learning. [Online] Available at: http://ollysofalhaj.ipgkti.edu.my/sumber/resosbestari// PENDEKATAN/scl/7\%20SCLNanney.pdf[Accessed 10 July 2015].

xii. Ossiannilsson, E. \& Landgren, L., 2012. Quality in E-Learning - A Conceptual Framework Based on Experiences from Three International Benchmarking Projects. Journal of Computer Assisted Learning, 28(1), pp. 42-51.

xiii. Palmer, P. \& Zajonc, A., 2010. The Heart of Higher Education. San Francisco: Jossey Bass.

xiv. Quality Assurance Agency (QAA), 2014. The Frameworks for Higher Education Qualifications of UK Degree-Awarding Bodies. [Online] Available at: http://www.qaa.ac.uk/publications/ information-andguidance/publication?PubID=2843\#. WFp1kv5XXIU[Accessed 22 January 2015].

xv. $\quad$ Rogers, C. \& Freiberg, H., 1994. Freedom to Learn. 3rd ed. New York: Merril.

xvi. Saunders, M., Bamber, R. \& Trowler, P., 2011. Reconceptualising Evaluation in Higher Education: the Practice Turn. London: McGraw-Hill Professional Publishing.

xvii. Sheail, P. \& Ross, J., 2014. Disrupting the Illusion of Sameness: The Importance of Making Place Visible In Online Learning. Edinburgh, UK, Proceedings of the Ninth International Conference on Networked Learning.

xviii. $\quad$ Smith, J., 2016. Experiencing Phenomenology. Abingdon: Routledge.

xix. $\quad$ Smith, J., Flowers, P. \& Larkin, M., 2009. Interpretative Phenomenological Analysis: Theory, Method and Research. London: Sage.

xx. Taylor, E. \& Snyder, M., 2012. A Critical Review of Research on Transformative Learning Theory 2006-2010. In: E. W. Taylor \& P. Cranton, eds. Handbook of Transformative Learning,Theory, Research, and Practice. San Francisco, CA: Jossey-Bass, pp. 37-54. 
xxi. Todhunter, B., 2013. Limitations of Online Learning, Are We Selling the Open and Distance Education Message Short. Distance Education, 34(2), pp. 232-252.

xxii. Zimmerman, B. \& Schunk, D., 2011. Handbook of Self-Regulation of Learning and Perfomance. New York: Routledge. 